Article type : Management Brief

Corresponding author mail id: tuftsb@queensu.ca

\title{
The importance of livewell transport in the physiological disturbance experienced by Smallmouth Bass in tournaments on large water bodies
}

Thomas C Brooke ${ }^{1}$, Connor W Elliott ${ }^{3}$, Jeremy Holden ${ }^{2}$, Yuxiang Wang ${ }^{3}$, Rachael L Hornsby $^{3}$, and Bruce L Tufts ${ }^{3 *}$

Author Affiliations:

${ }^{1}$ Current address: Fish and Wildlife Program, Sir Sandford Fleming College, Frost Campus, 200 Albert St S, Lindsay, ON K9V 5E6

${ }^{2}$ Lake Ontario Management Unit, Glenora Fisheries Station, Ontario Ministry of Natural Resources and Forestry, Picton, Ontario, Canada

${ }^{3}$ Department of Biology, Queen's University, Kingston, Ontario, Canada K7L 3N6

*Corresponding author: Freshwater Fisheries Conservation Lab, Department of Biology, Queen's University, Kingston, Ontario, Canada K7L 3N6

$<\mathrm{A}>$ Abstract

Competitive fishing has become an important element of recreational fisheries for black bass in North America. The vast majority of competitive events involve a "live-release" format where bass are held in a boat's livewell after being angled and are then released

This article has been accepted for publication and undergone full peer review but has not been through the copyediting, typesetting, pagination and proofreading process, which may lead to differences between this version and the Version of Record. Please cite this article as doi: 10.1002/nafm.10357

This article is protected by copyright. All rights reserved. 
following the weigh-in. We examined the frequency and importance of physical impacts between Smallmouth Bass (SMB) and the walls of the livewell when tournaments are held on large waterbodies. Using an experimental livewell that included a video recorder, we determined the number of collisions between SMB and the walls of the livewell when a $5.6 \mathrm{~m}$ boat was driven on Lake Ontario. During these experiments, 10 of 28 SMB lost equilibrium and became inverted. Livewell transport also resulted in elevations of intracellular enzymes in blood plasma used as indicators of cell damage. The results of these experiments indicate that physical impacts with the walls of the livewell may be an important factor contributing to the physiological disturbance experienced by SMB in tournaments on large waterbodies. Our results also show that this disturbance can be reduced by simply padding the livewell. These findings have important implications for fisheries managers, as well as the competitive angling community.

$<\mathrm{A}>$ Introduction

Competitive fishing has become an important component in North American fisheries (Schramm et al. 1991; Kerr and Kamke 2003; Schramm and Hunt 2007). Although there are competitive fishing events for a variety of species, the most commonly targeted species are black bass (Schramm et al. 1991; Kerr 2012). On many popular waterbodies, bass tournaments are now held on the majority of weekends during the open season. According to Driscoll et al. (2007), there were over 300 bass tournaments on Sam Rayburn Reservoir, Texas, in 2004. Large multi-day bass tournaments involving more than 100 participants are now also relatively common (Maynard et al. 2017). Growth in tournament-related fishing pressure, as well as continuous improvements in equipment (e.g. electronics), knowledge 
transfer and incentives have increased the probability that many of the largest adult fish in the fishery will be captured during these events (Nelson et al. 2017).

In an effort to minimize their impact on the resource, the vast majority of bass tournaments have adopted a "live-release" format. Although this format is designed to release fish alive after the tournament weigh-in, studies have shown that there is often some level of fish mortality associated with many of these events (Wilde 1998; Wilde et al. 2002; Edwards et al. 2004; Driscoll et al. 2007). Numerous studies have also attempted to identify the different factors that likely contribute to mortality and physiological impairment in tournament fish (reviewed in Siepker et al. 2007). In some cases, these studies have formed the basis of documents and/or recommendations for "best practices" to help organizers and anglers improve tournament procedures and increase the likelihood that fish will survive following their release after these events (Gilliland et al. 2002; Tufts and Morlock 2004). A better understanding of the different factors that influence the physiological condition and survival of fish involved in tournaments may therefore help to maintain the quality of fisheries where fish populations are frequently targeted during these events.

According to Kerr (2012), there has been an increase in the number of competitive fishing events on large water bodies, such as the Great Lakes, in recent years. Events on large water bodies may reduce some of the negative social issues that can be associated with tournaments (Kerr and Kamke 2003; Schramm and Hunt 2007). However, larger water bodies may also present some unique challenges with regard to fish care for tournament anglers and organizers. Improvements in boat design have enabled anglers to travel long distances in these events (Maynard et al. 2017), but even moderate winds on large expanses of open water can create very rough conditions. For these reasons, tournaments on large water bodies are renowned for the physical stresses they impose upon anglers and their 
equipment (boats, trolling motors). At this time, however, the additional stress these conditions may create for the fish has received no attention.

Evidence from previous studies on Walleye, Sander vitreus (Goeman 1991; Fielder and Johnson 1994) and Largemouth Bass, Micropterus salmoides (Kwak and Henry 1995) suggest that the physiological disturbance associated with livewell transport may be exacerbated during periods of high winds and rough water. According to Suski et al. (2005), the behaviour of walleye in response to increased wave action during livewell transport may also be a factor that contributes to increased tournament mortality of this species compared to Largemouth Bass. Taken together, the results of these previous studies suggest that livewell transport may be a significant problem for tournaments on large waterbodies, where higher waves are relatively common, but this issue has not been thoroughly examined.

The purpose of the present study is to improve our understanding of the factors affecting the physiological condition of bass involved in tournaments on large waterbodies. More specifically, we examine the frequency of the impacts between Smallmouth Bass and the walls of the livewell during extended periods of livewell transport on Lake Ontario. We also examine changes in indicators of cell damage associated with this disturbance and explore a potential solution that may improve the condition of transported fish in these situations.

$<$ A $>$ Methods

Study location.-

Experiments conducted in this study were all carried out in the eastern basin of Lake Ontario within about $20 \mathrm{~km}$ of Kingston, Ontario, Canada. Surveys of anglers involved in 
two bass tournaments (Quinte Angling Series and Canadian Bass Anglers Federation, Federation Cup) in which many anglers targeted Smallmouth Bass in the eastern basin of Lake Ontario were carried out in Belleville, Ontario. During the past decade, this location has been a popular site for bass tournaments in this region.

\section{Fish collection.-}

Smallmouth Bass used in all of these experiments were angled from Lake Ontario between June and mid-November using artificial lures and in a manner consistent with how they would be caught in tournaments. For this period, ambient surface water temperature ranged from $14.2{ }^{\circ} \mathrm{C}$ to $25.0{ }^{\circ} \mathrm{C}$ with a mean of $18.4{ }^{\circ} \mathrm{C}(\mathrm{SD}, 3.5)$. Only fish that exceeded 12 inches $(30.5 \mathrm{~cm})$ in total length and 1.5 pounds $(0.68 \mathrm{~kg})$ in weight were kept for experimentation. These criteria for fish size were used in order to adhere to tournament length standards and to ensure that the fish were similar to fish held in livewells by professional anglers within real tournaments. When fish were initially captured, they were immediately placed in the boat's built-in livewell with pumps running to continuously add fresh water. Angling continued in the same location until a maximum of 3 suitable fish were captured. This period of fish collection typically lasted less than 1 hour, so that the rest of the experiment could be completed with 1, 2 or 3 fish that had been caught.

\section{The experimental livewell.-}

A clear, 72 L 'plexiglass' tank (Length: $0.78 \mathrm{~m}$, Width: $0.31 \mathrm{~m}$, Depth: $0.31 \mathrm{~m}$ ) was constructed as an experimental livewell in order to allow video recording during the transportation period. Tank construction also incorporated a pressure sensor (Loadstar $\mathrm{Tr}$ 400, Loadstar Sensors, Fremont, California) at the front of the tank that measured changes in force $\left(\mathrm{ft}^{2} / \mathrm{lbs} / \mathrm{sec}\right)$ as an indication of the amount of water turbulence in the livewell. The sensitivity of this sensor is 0.01 pounds, the logging interval is every second and the optimal 
temperature range is $10{ }^{\circ} \mathrm{C}$ to $40{ }^{\circ} \mathrm{C}$. The tank set-up also included a water pump to ensure a constant supply of fresh water. Two wide-angle, waterproof digital video cameras $\left(\right.$ GoPro ${ }^{\mathrm{TM}}$ Hero $^{\mathrm{TM}}$ ) were mounted at the front and back of the tank to observe the orientation and activity of the fish. A digital thermometer was attached to the interior of the tank to monitor the water temperature throughout the experiment. At no time did the water temperature change by more than $2{ }^{\circ} \mathrm{C}$ between the beginning and the end of the experiment.

\section{Simulated livewell transport.-}

Surface water was collected from Lake Ontario and used to fill the experimental livewell. A maximum of 3 angled fish were transferred from the boat's built-in livewell to the experimental holding tank. The top of the tank was then secured using ratchet straps to ensure that the tank was water tight and would not move on the deck of the boat. The tank was secured on the rear deck of the boat lengthwise since this is the location of the livewells in most tournament bass boats. The fish were then transported for 60 minutes from their point of capture to a docking site. During the transportation sequence, the fish were recorded using the video camera described above. In order to facilitate identification of individual fish when analysing the video footage, each fish was color-coded using a small colored, spring-loaded lip clip. This type of color coding is often used in tournament angling to expedite the culling

of fish. The vessel used for these experiments was a Lowe TM $5.6 \mathrm{~m}$ deep V hull with a 150 horse-power Mercury Opti-max two-stroke outboard motor. This series of experiments involved 14 separate boat trips where 6 trips captured and transported 3 fish, 4 boat trips captured and transported 2 fish and 4 trips captured and transported 1 fish. For these experiments, surface water temperatures ranged from $14.2{ }^{\circ} \mathrm{C}$ to $25^{\circ} \mathrm{C}$ and the mean was 18.8 ${ }^{\circ} \mathrm{C}(\mathrm{SD}, 3.7)$. 
Following the period of transport in the experimental livewell, the fish were then placed in a different, dark and aerated holding tank for an additional 6 hours prior to sampling. This period of time was used to simulate additional holding time of fish in a livewell in a typical tournament which usually lasts about 8 hours. After the 6 hour holding period, a blood sample was taken using the methods described below and then the fish was released outside of the harbor once it had recovered from the anesthetic (60-ppm of clove oil).

Simulated transport in padded livewells.-

A second experimental series was conducted to determine whether the damage caused by impacts between fish and the walls of the tank could be reduced by padding the interior walls of the tank. These experiments were identical to those described above with the following exception: In these experiments, $5.1 \mathrm{~cm}$ thick soft foam $\left(\mathrm{Hero}^{\mathrm{TM}}\right.$ Cellulose multipurpose cleaning sponges) was added to the interior of the front and rear of the tank to reduce the impact between the fish and the wall of the tank. For this series of experiments, 9 fish were angled from Lake Ontario as in the previous experiment and transported in the experimental holding tank using the methods and equipment described above. This series of experiments involved 5 separate boat trips where 1 boat trip captured and transported 3 fish, 2 boat trips captured and transported 2 fish and 2 boat trips captured and transported 1 fish. For these experiments, surface water temperature ranged from $14.2{ }^{\circ} \mathrm{C}$ to $20.9{ }^{\circ} \mathrm{C}$ and the mean was $17.1^{\circ} \mathrm{C}(\mathrm{SD}, 2.3)$.

\section{Tournament sample collection.-}

Samples were also collected at a professional bass fishing tournament on Lake

Ontario in order to determine the levels of LDH and CPK found in Smallmouth Bass after a typical professional angling event held on a large body of water. In this case, 6 Smallmouth 
Bass were randomly selected from the live-release boat following the weigh-in. A relatively small number of fish were collected for this series because previous studies have also obtained values for these variables at real tournaments and this was simply to confirm that this study on Lake Ontario fish obtained values within the same range as those collected at other real tournaments (Morrissey et al. 2005).

\section{Blood sampling.-}

Approximately $3 \mathrm{ml}$ of blood was taken from all specimens using a $3 \mathrm{ml}$ syringe and 22 gauge needle rinsed in a heparinized saline solution (Morrissey et al. 2005). To obtain blood samples, fish were anesthetized by mixing a stock solution of clove oil in ethanol (1:10 ratio) with lake water to achieve a final concentration 60-ppm of clove oil (Anderson et al. 1997). Blood was taken from the branchial artery associated with the first gill arch on the left side of the fish. The blood was immediately placed in two, $1.5 \mathrm{ml}$ microcentrifuge tubes and spun in a centrifuge at $10,000 \mathrm{x}$ gravity for 3 minutes. The plasma was then immediately removed using a pipet and placed in a $1.5 \mathrm{ml}$ microcentrifuge tube. All tubes were then frozen in dry ice and transported back to the Biosciences complex at Queen's University. The samples were then transferred to the $-80{ }^{\circ} \mathrm{C}$ freezer for storage until processing.

\section{Control sample collection.-}

Six Smallmouth Bass were collected by angling on Lake Ontario as in the previous experiments and immediately sampled with no further handling. The purpose of this group was to obtain a blood sample before the intracellular enzymes used as indicators of cellular damage in this study would have had an opportunity to become significantly elevated in the blood stream. These samples provided values for angled fish with no holding time in a livewell, and this group was referred to as the angled (control) group for the remainder of this study. A second control group was collected by angling 5 Smallmouth Bass from Lake 
Ontario as in the previous experiments and holding them in a dark tank with circulating water and aeration for 6 hours before sampling. This group was collected to provide insight into the relative amount of cellular damage that is caused by the act of angling the fish and holding them without significant livewell transport. This group of fish was referred to as the resting control group for the remainder of this study.

\section{Plasma analysis.-}

Plasma samples were analyzed spectrophotometrically at a wavelength of $340 \mathrm{~nm}$, first for lactate dehydrogenase (LDH) using the method outlined by Wroblewski and LaDue (1955), and secondly, for creatine phosphokinase (CPK) following the method outlined by Hørder et al. (1990). In these analyses, a change in the concentration of a known amount of NADH (nicotinamide adenine dinucleotide, reduced) is used to quantitatively estimate the activity levels of both LDH and CPK which both act as catalysts in separate reactions. The levels of these intracellular enzymes in blood plasma are a useful indication of cell damage (Folmar et al 1993; Morrissey et al. 2005).

Survey of distances travelled by tournament anglers on Lake Ontario.-

In order to add further context to our study of livewell transport, we surveyed all tournament anglers from two bass tournaments on Lake Ontario (Quinte Angling Series and Canadian Bass Angler Federation events in 2014) with a single question. At the end of the tournament day, all teams who pursued Smallmouth Bass in these events $(\mathrm{N}=27)$ were asked how far they travelled (one way) to catch their limits. Responses were recorded and are reported in this study.

This article is protected by copyright. All rights reserved. 


\section{Data analysis.-}

All statistical analyses were conducted in R version 3.5.2 ( $\mathrm{R}$ Core Team 2018).

Functions from packages other than base are cited when noted. Impacts between fish and the livewell wall were considered for the full 60 minute duration of the test. During the initial experiment, 10 of the 28 fish lost equilibrium within the tank. The relationship between force and impact rate (impacts/min) was tested using a simple linear regression to gain insight into the importance of water turbulence in the livewell as a factor contributing to the number of impacts experienced by the fish within the livewell. Model assumptions were tested using the gvlma test which provides a global statistic to evaluate the assumptions of linear models and provides a $P$-value used to determine significant deviations from acceptable assumptions (Pena and Slate 2014). The model was tested and met all the assumptions of a linear model (gvlma global stat $=1.65 ; P$-value $=0.799)$. An outlier was identified but not deemed to be significantly influencing the model (Bonferroni $P$-value $=0.444$ ) when tested using the outlierTest function from the car package (Fox and Weisberg 2019).

The lme4 package (Bates et al. 2015) was used to perform a linear mixed effects analysis of the relationship between impacts per minute and various parameters within the livewell. For fixed effects, the model used fish length, orientation (normal vs. inverted), treatment (padded vs. unpadded livewells) and number of fish within the livewell (1-3) (without interaction term). The intercepts of individual livewell trips were used as the random effect term within the model. Water temperature was tested during early analyses and was not found to influence impacts per minute. Due to a relatively low sample size $(\mathrm{N}=42)$, water temperature was not included in the final model in order to avoid over-fitting the model with too many predictor variables. Using visual inspection of a leverage plot and the outlierTest fuction (Fox and Weisberg 2019), a single outlier was identified to be significantly influencing the model (Bonferroni $P$-value $=0.007$ ) and thus it was omitted from the final 
dataset. The model met all assumptions of a linear model including the absence of collinearity in the predictor variables. Visual inspection of residual plots did not reveal any obvious deviations from homoscedasticity or linearity. A Shapiro-Wilk test for normality was also used to test the normality of the residuals $(\mathrm{W}=0.971 ; P$-value $=0.397)$. Likelihood ratio tests comparing the full model with the effect in question against the model without the effect in question were used to obtain $P$-values for the significance of individual predictor variables.

The relationships between impact rate and the enzyme levels for LDH and CPK were tested using separate linear models. The gvlma function was used to test model assumptions for a linear model. Impact rate and $\mathrm{LDH}$, as well as impact rate and $\mathrm{CPK}$, met all the assumptions (LDH: gvlma global stat $=5.16 ; P$-value $=0.271$ and $\mathrm{CPK}$ : gvlma global stat $=$ $1.54 ; P$-value $=0.821)$

An ANOVA was conducted to test for a treatment effect and a Tukey Post Hoc test was used to determine differences in treatment groups when analyzing LDH and CPK enzyme levels. If data did not meet the assumptions of a linear model, a non-parametric Kruskal-Wallis rank sum test was used in place of an ANOVA. Treatment groups included the resting control group, the angled (control) group, the fish collected at tournaments and the fish transported in unpadded ('normal') and padded conditions. LDH data were $\log 10$ transformed to satisfy the assumptions of a linear model (gvlma global stat $=0.41 ; P$-value $=$ 0.396). A $\log 10$ transformation was conducted on the CPK data, however, the data still did not satisfy the assumptions of a linear model because there was significant heteroscedasticity in the data (gvlma global stat $=11.2 ; P$-value $=0.024)$. A Kruskal-Wallis rank sum test was therefore conducted on the untransformed CPK values to test for treatment effects and a post hoc comparison was conducted using the kruskalmc function in pgirmess (Giraudoux 2018). 
$<\mathrm{A}>$ Results

Results of 2 surveys of distances travelled by teams of tournament anglers $(\mathrm{N}=27)$ in pursuit of Smallmouth Bass in the eastern basin of Lake Ontario indicated that teams travelled substantial distances (Figure 1). The mean travel distance was $90.5 \mathrm{~km}$ (SD, 40.3) and 10 teams travelled $100 \mathrm{~km}$ or more. All but one of these teams travelled at least $50 \mathrm{~km} .\{-$ Figure1-\}

The mean number of impacts per minute between the fish and the walls of the experimental livewell are presented for 28 individual fish (Figure 2). For most fish, this value ranged between 5 and 15 impacts per minute and the mean value for this entire group of fish was $9.8(\mathrm{SD}, 11)$. It is important to note that there was a lot of variability between individual fish in these experiments. The lowest number of impacts in one minute for a fish was zero, and the greatest was $61 .\{$-Figure2- $\}$

The slope of the relationship between the mean force exerted by the water on the walls of the experimental livewell and the mean number of impacts experienced by the fish was significant (Figure 3; regression; $\mathrm{R}^{2}=0.50 ; \mathrm{df}=1,33 ; P$-value $<0.001$ ). This relationship indicates that the number of impacts experienced by the fish could be partially explained by the amount of turbulence exhibited by the water in the livewell. During these experiments, 10 fish in the experimental livewell lost equilibrium and were observed floating upside-down. These fish showed no signs of barotrauma after capture or upon immersion in the experimental holding tank and were simply categorized as inverted. \{-Figure $3-\}$

Impacts per minute were predicted using a linear mixed-effects model to address some of the differences in livewell conditions and individual variability demonstrated by the fish. The length of the fish and their orientation (normal vs. inverted) did not significantly affect the number of impacts per minute. The treatment (padded vs. unpadded) significantly 
affected impacts per minute (Likelihood ratio test; chi-squared $=4.754 ; \mathrm{df}=1 ; P$-value $=$ 0.029), increasing it for the padded group by 2.4 impacts (SE, 0.98). The number of fish in a livewell (1-3) significantly affected impacts per minute (Likelihood ratio test; chi-squared = 29.77; $\mathrm{df}=2 ; P$-value $<0.001)$. Increasing the number of fish in a livewell from 1 to 2 fish increased impacts by 3.6 impacts per minute (SE, 0.95) and from 1 to 3 fish it increased by 7.0 impacts per minute (SE, 1.05).

A linear model was used to test the relationship between impacts per minute and log transformed LDH values (Figure 4). There was a weak, yet significant, relationship between the impact rate and plasma LDH levels (regression; $\mathrm{R}^{2}=0.36$;f $=1,24 ; P$-value $=0.001$ ). In contrast, there was no relationship (data not shown) between the number of impacts and plasma CPK levels (regression; $\mathrm{R}^{2}=0.14 ; \mathrm{df}=1,24 ; P$-value $=0.062$ ). There were also no relationships (data not shown) between mean force values within the experimental livewell and plasma enzyme (LDH, CPK) levels. \{-Figure4- $\}$

Levels of $\mathrm{LDH}$ found in the plasma were compared for the treatment groups including the resting control group, the angled (control) group, the fish collected at tournaments and the fish transported in unpadded ('normal') and padded conditions (Figure 5A). A single factor ANOVA showed that there is a significant difference between the levels of LDH found in the groups $($ ANOVA; $F$-value $=4.587 ; \mathrm{df}=4,49 ; P$-value $=0.003)$. A Tukey post-hoc test showed that the unpadded treatment group and tournament group had significantly higher levels of LDH than the angled control group $(P$-value $<0.05)$. In addition, the LDH values in the padded treatment group were not significantly different than those in either of the control groups. There was a similar trend for CPK levels among the different treatment groups (Figure 5B). A Kruskal-Wallis test showed that there is a significant difference between the levels of CPK found in the groups (Kruskal-Wallis test, chi-squared $=15.22 ; \mathrm{df}=4 ; P$-value $=0.004)$. A subsequent multiple comparison post-hoc test indicates that the unpadded 
treatment group has a significantly higher level of CPK than the angled control group (obs. diff $=23.31 ;$ crit. diff. $=21.44)$, and the padded group has a significantly lower level of CPK than the unpadded group (obs. diff $=17.02$; crit. diff. $=16.92) .\{$-Figure5- $\}$

$<\mathrm{A}>$ Discussion

The results of earlier studies (Goeman 1991; Fielder and Johnson 1994; Kerr and Kamke 2003; Suski et al. 2005; Graeb et al. 2005; Schramm and Hunt 2007), as well as our anecdotal observations during many years of research at tournaments, suggest that physical impacts between the fish and the walls of the livewell could be an important issue for some species of fish in tournaments on large water bodies. The results from this study now provide direct evidence that this may be a critical factor affecting the condition of Smallmouth Bass after tournaments on bodies of water such as the Great Lakes.

It is not unusual for anglers to travel relatively long distances in tournaments on large water bodies. According to Maynard et al. (2017), anglers involved in tournaments on Lake Champlain commonly travel over $100 \mathrm{~km}$ from sites where fish are caught to the weigh-in site. Results of surveys conducted in the present study showed that long travel distances are also common for bass tournament anglers on Lake Ontario. Although these distances may only require about an hour of travel in calm water, they may take several hours when high winds and rough conditions occur. Since tournaments on large waterbodies have become more common (Kerr 2012) and may often involve more than a hundred anglers (Maynard et al. 2017), many of the largest bass in these waterbodies are now experiencing relatively long periods of livewell transport during the angling season.

This article is protected by copyright. All rights reserved. 
Suski et al. (2005) previously reported that Walleye collided with the walls of the livewell when wave intensities increased while a boat was driven on a relatively small lake. The same study reported that Largemouth Bass were better able to avoid these collisions, but this research was primarily focused on behavioural differences between these species and did not attempt to quantify collisions with the walls of the livewell or their impact on the condition of the fish. In the present study, we show that Smallmouth Bass also frequently collide with the walls of the livewell when a boat is driven on a large waterbody such as Lake Ontario. Based on the information obtained for the frequency of impacts provided by our experiments, it is likely that travel distances similar to those reported by anglers in our surveys, as well as in Maynard et al. (2017), would be associated with several hundred impacts between the fish and the walls of the livewell during the tournament day.

The results of our study provide convincing evidence that the overall effect of these collisions between Smallmouth Bass and the walls of the livewell has important consequences for the fish. As in previous studies (Folmar et al. 1993; Morrissey et al. 2005) we monitored the plasma concentrations of two intracellular enzymes ( $\mathrm{LDH}$ and CPK) as indicators of cell damage. Increases in the levels of these enzymes in blood plasma after collisions between the fish and the walls of the livewell indicate that these impacts caused injuries in our experimental fish. The loss of equilibrium in some of these fish also suggests that some of these collisions, or their cumulative impact, can have serious consequences. The results of Morrissey et al. (2005), as well as the present study, show that plasma levels of LDH and CPK are also elevated in Smallmouth Bass following real tournaments on large waterbodies. Interestingly, the magnitude of the increase in our experimental fish is very similar to that occurring in Smallmouth Bass during real events. This observation suggests that a considerable amount of the cell damage occurring in Smallmouth Bass during real tournaments could be explained by collisions with the walls of the livewell. 
Barotrauma is another important factor that causes elevations in the indicators of cell damage monitored in this study (Morrissey et al. 2005) and can have a profound impact on the overall condition of tournament fish (Gravel and Cooke 2008). In view of this, an effort was made to catch our experimental fish from relatively shallow $(<5 \mathrm{~m})$ water, so that this was not a factor that would complicate the interpretation of our results. We also monitored our fish for other external signs of barotrauma such as bloating, as well as hemorrhaging inside the mouth and fins (Feathers and Knable 1983; Morrissey et al. 2005) and none of these additional symptoms were observed. Additional results in our experiments also provide evidence that the disturbances observed in our experimental fish were likely caused by collisions with the walls of the livewell and were not due to barotrauma. Although some of the fish in our experiments lost equilibrium during the experiments, this never occurred in our control group. Most importantly, a final series of experiments demonstrated that the significant elevations in enzymes used as indicators of cell damage could be eliminated if padding was added to the walls of the livewell. It is also noteworthy that none of the 9 fish in the padded livewells became inverted during these experiments.

In the present study, we monitored the changes in force of the water inside the experimental livewell in order to gain further insight into the causes of the disturbance experienced by Smallmouth Bass. As would be expected, greater turbulence of the water inside the livewell did make it more difficult for the fish to avoid contact with the walls of the livewell. The fact that the relationship between these two variables was not stronger, however, suggests that there may also be other important factors that influence the ability of fish to avoid contact with the walls of the livewell. In a previous study, Largemouth Bass were found to exhibit behavioural responses to increased turbulence that helped them avoid collisions with the walls of the livewell (Suski et al. 2005). Since fish were angled prior to livewell transport in our experiments, it is possible that the relative condition of individual 
fish after angling (state of exhaustion/recovery) affected these behavioural responses. Another important factor that may influence the ability of fish to avoid impacts with the walls of the livewell is the density of fish being held. According to our results, the numbers of impacts was greater when there were more fish held in the live well. Although the scope of the current investigation into this issue was limited, these findings warrant further investigation and may have important implications for live-release tournaments.

An important variable that we were unable to directly measure in this study was the force of the impacts between the fish and the walls of the livewell. However, the video recordings showed that there was probably considerable variation in the force associated with these collisions. Many collisions appeared to be relatively minor, while others were clearly more severe. This variability in the nature of the collisions would explain why there was not a stronger relationship between the number of impacts and the levels of enzymes used to indicate cell damage. As observed for Largemouth Bass (Suski et al. 2005), Smallmouth Bass spent the majority of time trying to orient themselves so that they were parallel to the direction of water movement and with their head oriented towards the bow end of the livewell. This positioning resulted in many collisions between the head of the fish and the front end of the livewell. Head injuries resulting from this orientation during severe impacts may also explain why some fish become inverted in these experiments.

In our study, the experimental livewell was placed on the surface of the back deck of the boat because it provided a large surface to accommodate all of the experimental apparatus. In most tournament bass boats, the livewells are also located at the back of the boat, but below the deck. It is possible that greater turbulence might have occurred because our experimental livewell was on the surface of the deck. There are probably also several factors, however, that would contribute to greater turbulence in livewells in real tournaments on Lake Ontario. For example, the boat used in our study was smaller (5.6 m) and less 
powerful (150 HP) than most tournament boats used on the Great Lakes ( $>6 \mathrm{~m},>200 \mathrm{HP})$. During our experiments, wave heights ranged from 0.1 to $0.9 \mathrm{~m}$ with a mean of $0.5 \mathrm{~m}$ (SD, 0.3), but days with higher waves are also common on Lake Ontario. In actual events on large waterbodies, such as Lake Erie and Lake Ontario, it is not unusual for some competitors to experience boat damage (pressure cracks, broken transoms and damaged trolling motors) as a result of the forces generated between waves and boats travelling at very high speeds in rough water. In the present study, there was no attempt to re-create the extreme nature of these situations, but one can speculate that these situations would likely result in even larger disturbances in the fish during livewell transport. The fact that rough water conditions have been associated with greater fish mortality in some studies provides additional evidence to support this conclusion (Goeman 1991; Fielder and Johnson 1994).

The use of live-release as a strategy to conserve bass populations has resulted in a large body of research to maximize the benefits of this practice (reviewed in Siepker et al. 2007). The current study provides additional information in this area that could be used to improve the condition of bass captured in live-release tournaments. Most importantly, this study shows that livewell transport may be an important factor affecting the condition of Smallmouth Bass in tournaments on large waterbodies such as the Great Lakes. In recent years, several companies have developed new models of tournament-style boats that are specifically intended for improved performance on large water bodies. In addition to the different volumes, shapes and locations of livewells that companies provide, the results of this study indicate that some form of livewell padding might also be important to consider when designing these boats. In the present study, only a limited number of experiments were conducted to evaluate whether the condition of the fish could be improved by alterations to the livewell, but these results suggest that further investigations in this area are clearly warranted. This research has important implications for fisheries management, companies 
producing boats intended for tournament angling on large waterbodies, as well as tournament organizers and participants.

\section{$<$ A $>$ Acknowledgments}

Financial support for this study was provided by Shimano Canada Ltd and the Greenberg Family Fund for the Conservation of Freshwater Fisheries at Queen's University. Zachery Wells and Sean Bridgeman assisted with preparation of the manuscript. We would also like to acknowledge the cooperation of tournament anglers in the Quinte Fishing Series and Canadian Bass Anglers Federation who participated in our surveys.

$<\mathrm{A}>$ References

Anderson, W. G., R. S. McKinley, and M. Colavecchia. 1997. The use of clove oil as an anesthetic for Rainbow Trout and its effects on swimming performance. North American Journal of Fisheries Management 17(2):301-307.

Bates, D., M. Maechler, B. Bolker, and S. Walker. 2015. Fitting linear mixed-effects models using lme4. Journal of Statistical Software, 67(1):1-48.

Driscoll, M. T., J. L. Smith, and R. A. Myers. 2007. Impact of tournaments on the Largemouth Bass population at Sam Rayburn Reservoir, Texas. North American Journal of Fisheries Management 27(2):425-433.

Edwards, G. P., R. M. Neumann, R. P. Jacobs, and E. B. O’Donnell. 2004. Factors related to mortality of black bass caught during small club tournaments in Connecticut. North American Journal of Fisheries Management 24(3):801-810.

Feathers, M. G., and A. E. Knable. 1983. Effects of depressurization upon Largemouth Bass. North American Journal of Fisheries Management 3:86-90.

Fielder, D. G., and B. A. Johnson. 1994. Walleye mortality during live-release tournaments on Lake Oahe, South Dakota. North American Journal of Fisheries Management 14(4):776-780.

This article is protected by copyright. All rights reserved. 
Folmar, L. C., S. Bonomelli, and J. Gibson. 1993. The effect of short-term exposure to three chemicals on the blood chemistry of the pinfish (Lagodon rhomboides). Archives of Environmental Contamination and Toxicology 24:83-86.

Fox, J., and S. Weisberg. 2019. An $\{\mathrm{R}\}$ companion to applied regression. Third Edition. Thousand Oaks, California.

Gilliland, G., H. Schramm, and B. Shupp. 2002. KEEPING BASS ALIVE: A Guidebook for Anglers and Tournament Organizers. ESPN Productions Inc./B.A.S.S., Montgomery, Alabama.

Giraudoux, P. 2018. pgirmess: Spatial analysis and data mining for field ecologists. R package version, 1(6.9).

Goeman, T. J. 1991. Walleye mortality during a live-release tournament on Mille Lacs, Minnesota. North American Journal of Fisheries Management 11(1):57-61.

Graeb, B.D.S., J.L. Shepherd, D.W. Willis, and J.S. Sorensen. 2005. Delayed mortality of tournament-caught Walleyes. North American Journal of Fisheries Management 25:251255 .

Gravel, M.-A., and S. J. Cooke. 2008. Severity of barotrauma influences the physiological status, postrelease behavior, and fate of tournament-caught Smallmouth Bass. North American Journal of Fisheries Management 28(2):607-617.

Hørder, M., R. C. Elser, W. Gerhardt, M. Mathieu, and E. J. Sampson. 1990. IFCC methods for the measurements of catalytic concentration of enzymes. VII, IFCC method for creatine kinase (ATP : creatine N-phosphotransferase, EC 2.7.3.2.). IFCC recommendation. Clinica chimica acta 190(1-2):S4-S17.

Kerr, S. J. 2012. A survey of 2012 competitive fishing events in Ontario. Fisheries Policy Section, Biodiversity Branch. Ontario Ministry of Natural Resources. Peterborough, Ontario.

Kerr, S. J., and K. K. Kamke. 2003. Competitive fishing in freshwaters of North America. Fisheries 28(3):26-31.

Kwak, T. J., and M. G. Henry. 1995. Largemouth Bass mortality and related causal factors during live-release fishing tournaments on a large Minnesota Lake. North American

This article is protected by copyright. All rights reserved. 
Journal of Fisheries Management 15(3):621-630.

Maynard G. A., T. B. Mihuc, V. A. Sotola, D. E. Garneau, and M. H. Malchoff. 2017. Black bass dispersal patterns following catch-and-release tournaments on Lake Champlain. North American Journal of Fisheries Management 37:524-535.

Metcalfe, N.B., T.E. Van Leewen and S.S. Killen. 2016. Does individual variation in metabolic phenotype predict fish behaviour and performance? Journal of Fish Biology 88:298-321.

Morrissey, M. B., C. D. Suski, K. R. Esseltine, and B. L. Tufts. 2005. Incidence and physiological consequences of decompression in Smallmouth Bass after live-release angling tournaments. Transactions of the American Fisheries Society 134(4):1038-1047.

Nelson, E. J. H., J. Holden, R. Eves, and B. L. Tufts. 2017. Comparison of diets for Largemouth and Smallmouth Bass in Eastern Lake Ontario using DNA barcoding and stable isotope analysis. PLoS ONE. 12:e181914.

Pena, E.A., and E.H. Slate. 2014. gvlma: Global validation of linear models assumptions. R package version, $1(0.2)$.

R Core Team. 2018. R: A language and environment for statistical computing. R Foundation for Statistical Computing, Vienna, Austria.

Schramm, H. L., and K. M. Hunt. 2007. Issues, benefits, and problems associated with fishing tournaments in inland waters of the United States: A survey of fishery agency administrators. Fisheries 32(5):234-243.

Schramm, H. L., M. L. Armstrong, N. A. Funicelli, D. M. Green, D. P. Lee, R. E. Manns, B. D. Taubert, and S. J. Waters. 1991. The status of competitive sport fishing in North America. Fisheries 16(3):4-12.

Siepker, M. J., K. G. Ostrand, S. J. Cooke, D. P. Philipp, and D. J. Wahl. 2007. A review of the effects of catch-and-release angling on black bass, Micropterus spp.: implications for conservation and management of populations. Fisheries Management and Ecology 14:91-101.

Suski, C. D., S. J. Cooke, S. S. Killen, D. H. Wahl, and B. L. Tufts. 2005. Behaviour of Walleye, Sander vitreus, and Largemouth Bass, Micropterus salmoides, exposed to 
different wave intensities and boat operating conditions during livewell confinement. Fisheries Management and Ecology 12(1):19-26.

Tufts, B., and P. Morlock. 2004. The Shimano water weigh-in system: a "fish-friendly" guide. Page Shimano Sport Fisheries Initiative. Whitney, Ontario.

Wilde, G. R. 1998. Tournament-associated mortality in black bass. Fisheries 23(10):12-22.

Wilde, G. R., C. E. Shavlik, and K. L. Pope. 2002. Initial mortality of black bass in B.A.S.S. fishing tournaments. North American Journal of Fisheries Management 22(3):950-954.

Wroblewski, F., and J. S. LaDue. 1955. Lactic dehydrogenase activity in blood. Experimental Biology and Medicine 90(1):210-213.

This article is protected by copyright. All rights reserved. 


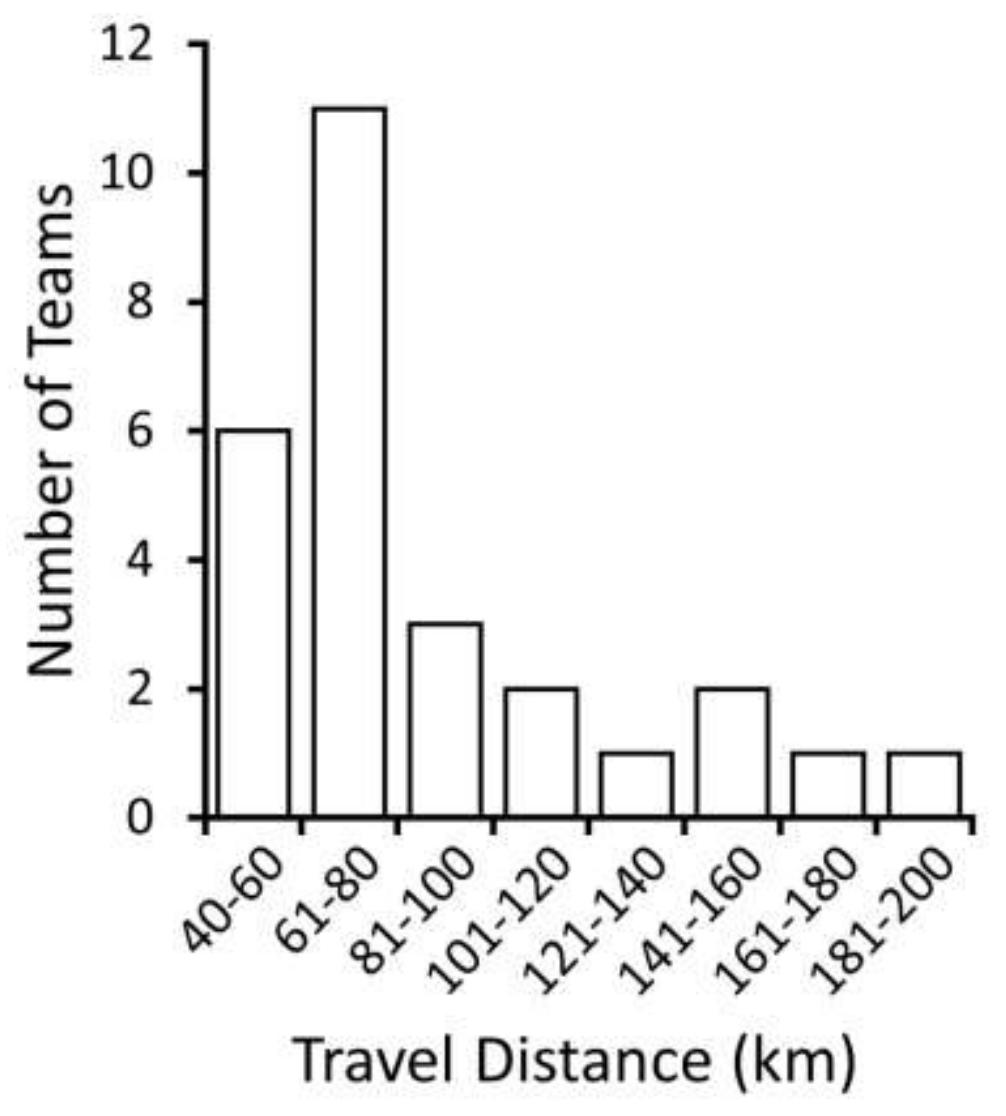

This article is protected by copyright. All rights reserved. 


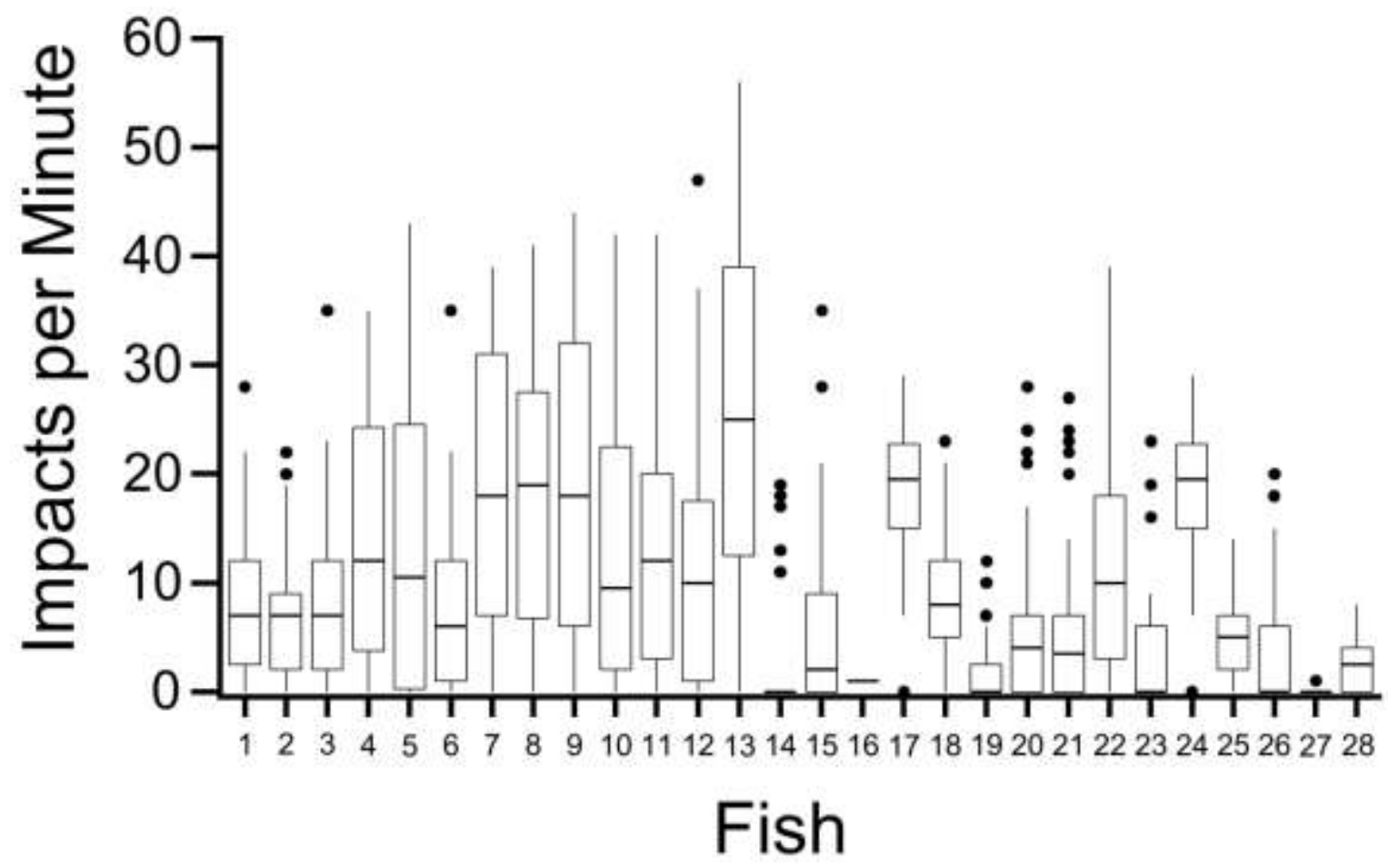

This article is protected by copyright. All rights reserved. 


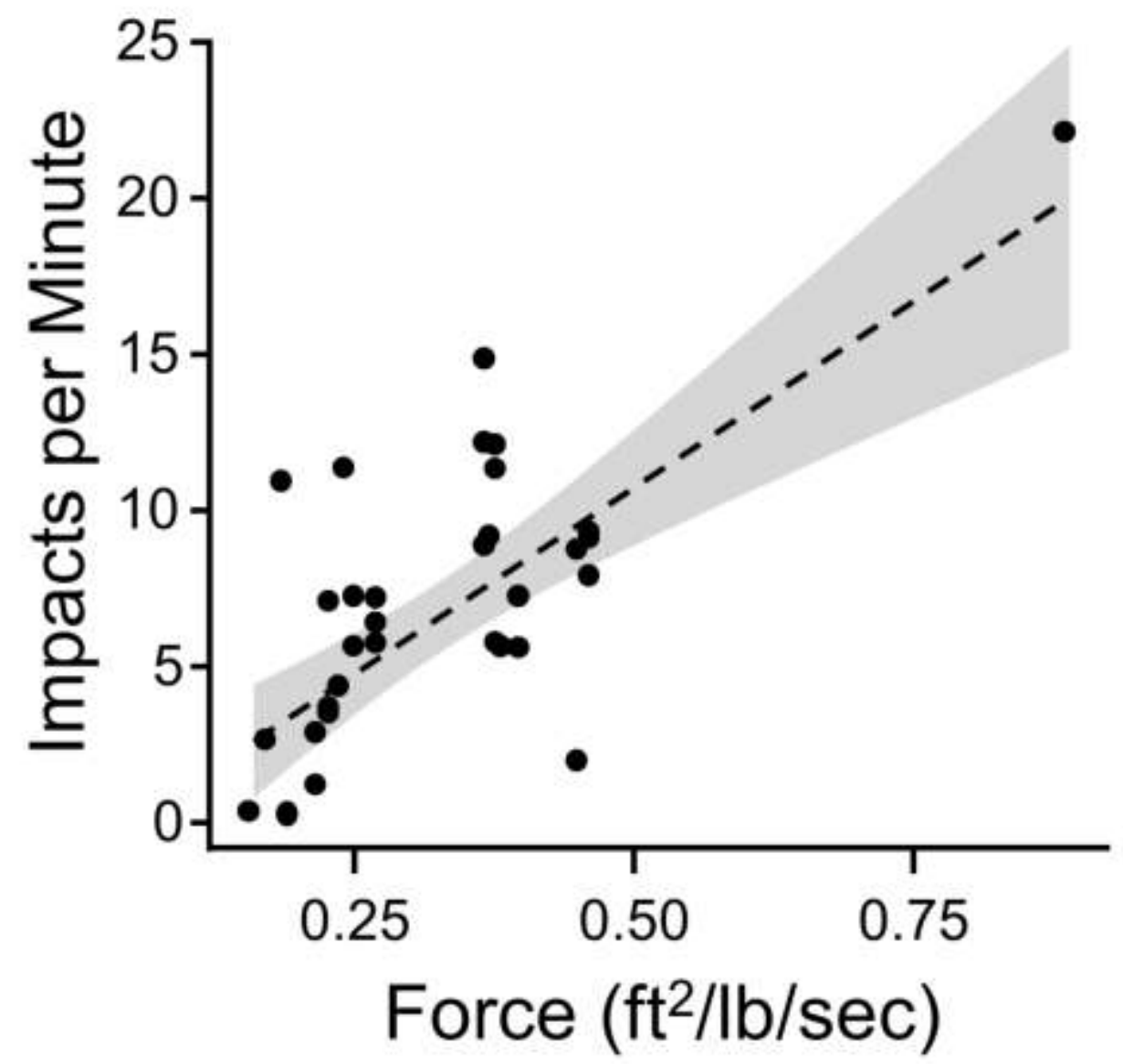

This article is protected by copyright. All rights reserved. 


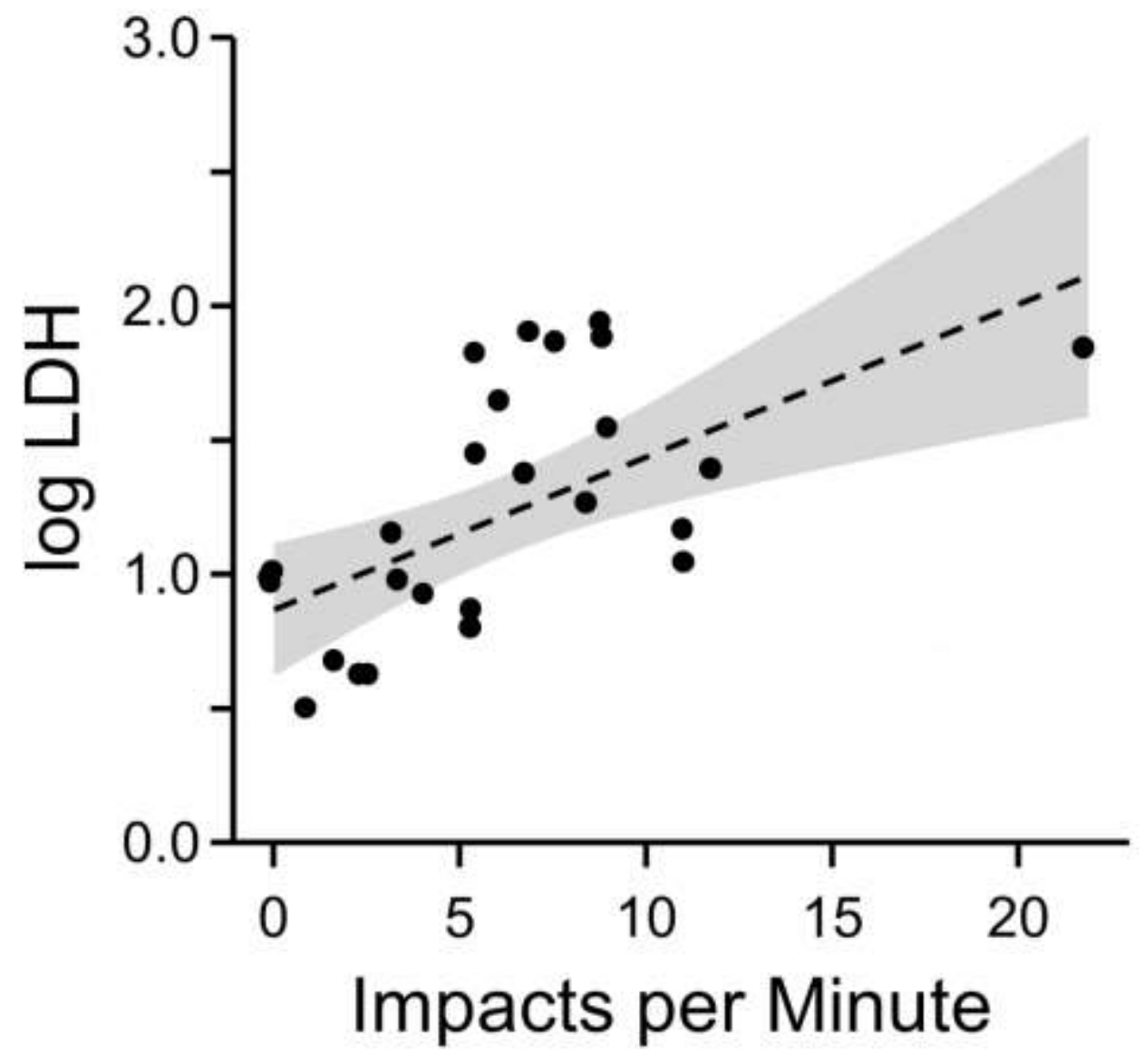

This article is protected by copyright. All rights reserved. 
A

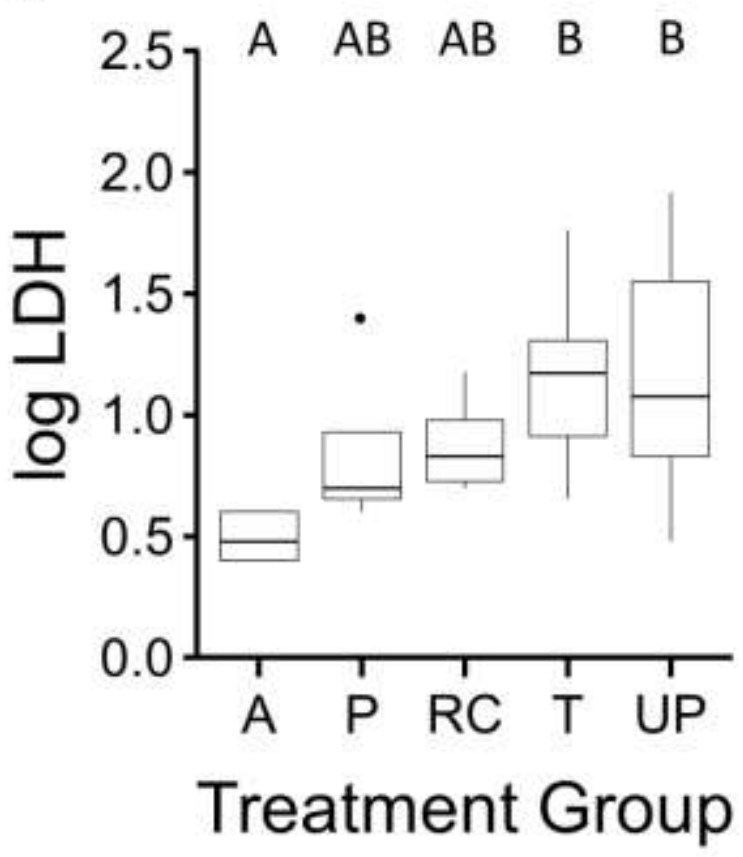

B

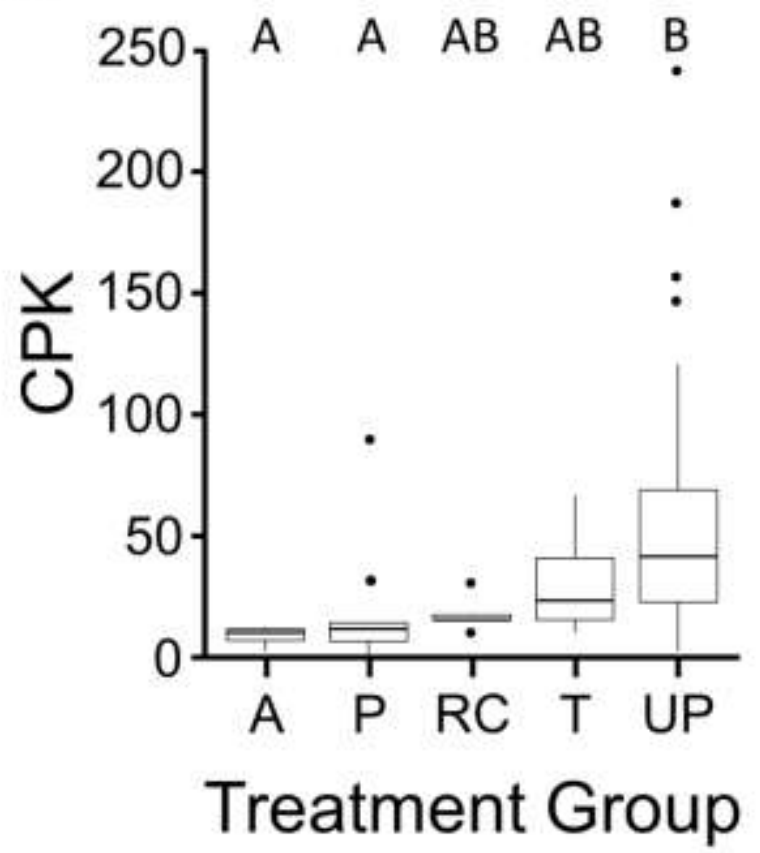

